\title{
Study of Wastewater Treatment Plants in Operation with UASB Reactors in the Municipality of Juazeiro do Norte-Ceará
}

Francisco de Assis Martins Ponce ${ }^{1}$, João Paulo Leite Félix ${ }^{2}$, André Gadelha de Oliveira ${ }^{1}$ and Ricardo Leandro Santos Araújo ${ }^{1}$

1. Center of Technological Sciences, University of Fortaleza, Fortaleza 60811-905, Brazil

2. Department of Civil Construction, Federal Institute of Education, Science and Technology of Ceará, Fortaleza 60040-531, Brazil

\begin{abstract}
The indiscriminate release of effluents without any type of treatment, or previous treatment without adequate disinfection, can cause several inconveniences for the water body and society, including water-borne diseases. In the present study, the physicochemical and biological aspects of three WWTPs (Wastewater Treatment Plants) operated with UASB (Upflow Anaerobic Sludge Blanket) technology in Juazeiro do Norte were analyzed in order to verify the state of Ceará State legislation, compliance with standards for the release of domestic effluents into bodies' receptors. In the research, it verified that the stations did not meet the effluent release standards for TSS (Total Suspended Solids) and removal of Escherichia coli in several analyzed months. It also verified that the UASB stations need a post-treatment in order to assist in the process of removal of organic matter and pathogens.
\end{abstract}

Key words: Effluent, UASB, analyze.

\section{Introduction}

Sewage is defined as water supply to a community after its use in a variety of applications [1]. This wastewater contains approximately $99.9 \%$ water and the remaining fraction includes organic, inorganic solids, solvents, paper, plastic, detergents as well as microorganisms, and due to the degree of pollution, they must be treated properly before returning to the environment $[2,3]$.

The indiscriminate release of effluents without any type of treatment, or previous treatment without adequate disinfection, can cause several inconveniences for the water body and society, including water-borne diseases due to the contribution of organisms from the "coliform group" $[3,4]$.

The pollution of these water resources causes a number of problems, which tend to worsen over time because of misuse and anthropic activities developed

Corresponding author: Francisco Ponce, bachelor degree, main research field: residual water. along the river basin [5].

Consequences of water pollution affect ecological, social or economic fields [4, 5]: (1) Damage to the human supply, making it a vehicle for the transmission of diseases; (2) Damages to multiple uses of water such as recreation, industrial, fishing; (3) Worsening problems of good quality water scarcity; (4) Elevation in the cost of water treatment, therefore, the increase of the tariff paid to the population; (5) Injury to fish and other aquatic organisms, with ecological imbalance; (6) Excessive algae proliferation (eutrophication); (7) Reduction of the average life of the population; (8) Higher incidence of diseases; (9) Increased hospital costs; (10) Increase in infant mortality and (11) Reduced productivity at work.

Over a period of 9 years (2001 to 2009), diseases such as diarrhea and dengue, which are related to lack of sanitation, were responsible for more than $93 \%$ of hospitalizations in Brazil [6].

In the Garulhos region, in the city of São Paulo, Brazil, in 2005 and 2006, they reported that cases of diarrhea in 
children were 15 times more frequent for populations with precarious housing and lack of adequate access to basic sanitation [7]. The mortality from this disease is a pointer to be considered in Public Health, given the responsiveness of various changes in conditions of access to adequate sanitation, food quality and behaviors of an individual in a community [8].

Juazeiro do Norte is located in the southern state of Ceará, with a population of 249,939 , the climate is tropical hot with average temperatures of $25^{\circ} \mathrm{C}$ [9]. The hot climate is ideal for adoption of UASB (Upflow Anaerobic Sludge Blanket), technology due to the development of organisms in the anaerobic phase at temperatures above $20{ }^{\circ} \mathrm{C}$, and the reactor heating process is unnecessary [2, 10-13].

This type of reactor was created in the 1970 s by teacher Lettinga and his team from the University of Wageningen-Netherlands, characterized by a three-phase separation system: solid, liquid and gaseous. Sewage with high concentrations of pollutants, being applied in domestic wastewater with low concentrations of organic matter from the middle of 1995 [4, 10, 14]. A great diversity of organic effluents, even those that previously were not believed to be possible to treat anaerobically, are now treated using UASB [15].

In the 1980s, feasibility studies of the UASB reactors were started, which were highlighted in the operational cost, high rates of sewage treatment, possibility of energy production for methane gas and attractive cost. However, improper use, without great knowledge about this type of technology, has eroded its image in front of us and several sanitation companies [16].

The UASB reactors can be a good option for small Brazilian municipalities when compared to other technologies, mainly due to the low cost of construction and maintenance, besides the possibility of the energetic use of the biogas generated $[17,18]$. Among the main advantages and disadvantages of UASB type reactors, it is possible to highlight in Table 1.

The Resolution COEMA (State Environmental Council) No. 02/2017 Article 12 governs launch standards for domestic sewage [19].

According to the Public Services Regulatory Agency and Delegates of the State of Ceará, ARCE [20], the wastewater system of Juazeiro do Norte consists of five WWTPs (Wastewater Treatment Plants): (1) WWTP Malvas-2 Anaerobic Lagoons +2 Facultative Ponds + 1 Maturation Lagoon; (2) WWTP Vila Três Marias-UASB + Contact Tank with Chlorination + Sludge Drying Bed; (3) WWTP Tenente Coelho-2 UASB +2 SAFs (Submerged Aerated Filters) +2 Decanters + Chlorination +2 Sludge Drying Beds; (4) WWTP Mutirão-2 UASB +5 Contact Tanks +4 Mud Drying Beds; (5) WWTP Prourb - 8 Septic Tanks +8 Anaerobic Filters + Chlorination.

Information obtained from the National Sanitation Information System [21], showed that in Juazeiro do Norte in the period from 2006 to $2016,26,801.71 \mathrm{~m}^{3}$ of sewage was collected and treated. The Water and Sewage Company of Ceará (CAGECE) is the concessionaire responsible for the collection and treatment of sewage in the municipality. Juazeiro do

Table 1 Characteristics of UASB reactors $[1,10]$.

\begin{tabular}{|c|c|}
\hline Positives & Negatives \\
\hline 1. Lower power consumption. & 1. Possibility of emanation of bad odors and corrosive gases. \\
\hline 2. Lower production of biological sludge. & 2. Longer starting period for biomass development required. \\
\hline 3. Less need for nutrients. & $\begin{array}{l}\text { 3. It may require additional treatment by an aerobic treatment process to } \\
\text { meet effluent emission standards. }\end{array}$ \\
\hline 4. Production of methane, energy source. & 4. It does not allow the biological removal of nitrogen and phosphorus. \\
\hline 5. Lower reactor volume. & 5. Very sensitive to the negative effects of low temperature. \\
\hline 6. Elimination of air pollution by exhaust gases. & 6. Low system capacity to tolerate toxic loads. \\
\hline $\begin{array}{l}\text { 7. Satisfactory removal of BOD and COD (Chemical Oxygen } \\
\text { Demand), in order of } 65 \text { to } 75 \% \text {. }\end{array}$ & 7. May require addition of alkalizing agent. \\
\hline
\end{tabular}


Norte has $21.99 \%$ of collected sewage, being among the 15 worst municipalities of the 100 surveyed, in investments in the area of sanitation [22].

In view of the above, the objective was to verify the environmental suitability, removal of COD and compliance with the state legislation of treated effluents from stations that use UASB reactors as a type for the treatment of domestic effluents from Juazeiro do Norte.

\section{Material and Methods}

The study was carried out based on documentary research and data from the inspection reports of the State Regulatory Agency of Ceará, responsible for the supervision of water and sewage services in Juazeiro do Norte. The research considered the data $(\mathrm{pH}, \mathrm{COD}$, TSS (Total Suspended Solids) and E. coli) of the effluents treated in the WWTP Vila Três Marias, WWTP Tenente Coelho and WWTP Mutirão na (Fig. 1) due to the importance of these parameters in the operational control as well as a greater frequency of analysis of these parameters by the concessionaire, benefiting a greater credibility of the information analysis.

According to the Sampling Plan for Sewage Quality Monitoring [23], for anaerobic reactor type technologies, with and without post-treatment, monthly analyses of the raw sewage are carried out and only treated for the COD parameter, thus making it impossible to evaluate the efficiency of other physicochemical and biological parameters of the seasons.

\subsection{Description of the UASB Reactors in Juazeiro do Norte}

\subsubsection{Vila Três Marias}

The Vila Três Marias WWTP, receives contributions from Vila Três Marias community, the effluent sent to a lifting station equipped with railing, sandbox with Parshall gutter, suction well with self-priming pump and generator set power. After the preliminary treatment, the sewage is sent to the contact tank where chlorine is applied for disinfection and the final destination is the Salgado River [20]. The quality of the Salgado river is compromised, an important fact, given that the waters of this river will be used for the transposition of the São Francisco river [24].

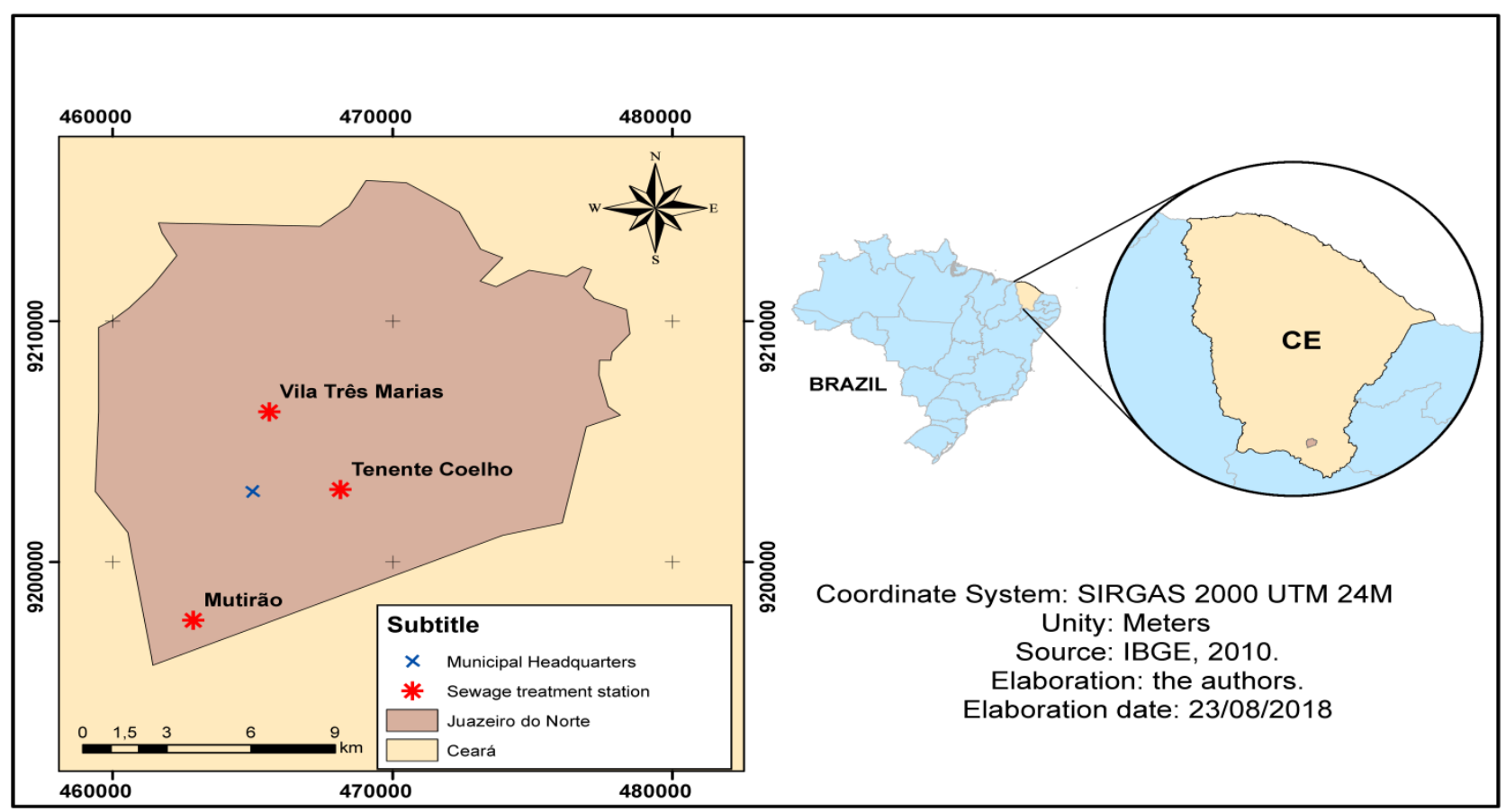

Fig. 1 Location of the UASB stations in Juazeiro do Norte. 


\subsubsection{Tenente Coelho}

The station receives an exclusive contribution from Tenente Coelho residential condominiums through a condominial collection network that drains the effluents, soon after it sent to the preliminary treatment with railing and sandbox with flow measurement in the Parshall gutter. This preliminary treatment is essential to preserve the pump motor assembly, which then sends the primary treatment sewer to two UASB reactors. The improvement of UASB effluent quality at the secondary level will be achieved through the application of a fixed film aerobic biological reactor, in this case an SAF was used as secondary sewage treatment. In practice this type of unit constituted of a tank, where in its interior there will be a filling (half support). As the filler does not retain the biomass, it is necessary to decant downstream of the reactor [4]. To do so, the ASF effluent will pass through a settling unit obtained with the use of parallel plates, called the SD (Secondary Decanter). After this process, the effluent will be sent for disinfection with chlorine and will pass into a contact tank. Finally, the final destination is the Salgado River [20].

\subsubsection{Mutirão}

It receives the contribution of the housing complex Frei Damião, where it passes through an elevation with well sand, railing and suction well with submersible pumps. Subsequently, the effluent is repressed to an equilibrium tower for the purpose of breaking the pressure so was not to cause operational problems in the UASB reactors which soon follow after the tower. After the anaerobic treatment in the $\mathrm{UASB}$, the first one is directed to the five contact tanks, where it was disinfected with chlorine, and finally, the final destination is disposed of in a soil near the station [20].

\subsection{Launch Patterns}

Regarding the launching standard, the final quality of the WWTP effluent was evaluated in compliance with the standards established by the SEMACE (State Environmental Authority, Ceará), contained in the COEMA no. 02, dated February 21, 2017, which on standards and conditions for the discharge of liquid sources (Table 2).

\subsection{Efficiency of Removal of Organic Compounds}

In order to calculate the efficiency of COD removal at the stations studied [3], Eq. (1):

$$
E=\left(\frac{A_{C}-E_{C}}{A_{C}}\right) \cdot 100
$$

where:

" $E$ " is removal efficiency (\%);

" $E_{c}$ " is efluent concentration in $\mathrm{mL}$;

" $A_{c}$ " is afluent concentration in $\mathrm{mL}$.

The same methodology was used in other studies on effluent treatment $[12,25,26]$.

\section{Results and Discussion}

\subsection{COD Removal Efficiency}

The efficiency of COD removal at the stations that operated with UASB in Juazeiro do Norte, is observed according to Fig. 2, that from March to November of 2017, the station Mutirão, although the WWTP did not obtain an aerobic treatment to guarantee the improved

Table 2 Standard of release of domestic effluents from state legislation [19].

\begin{tabular}{lll}
\hline \multicolumn{2}{c}{ Resolution standards No. 02/2017 art. 12, COEMA } \\
\hline Parameter & Unity & Maximum value \\
$\mathrm{pH}$ & - & $5.0-9.0$ \\
$\mathrm{COD}$ & Not specified & \\
$\mathrm{TSS}$ & $\mathrm{mg} / \mathrm{L}$ & 100.0 \\
E. coli & Number of CFU (Colony Forming Units) $/ 100 \mathrm{~mL}$ & 5,000 \\
\hline
\end{tabular}




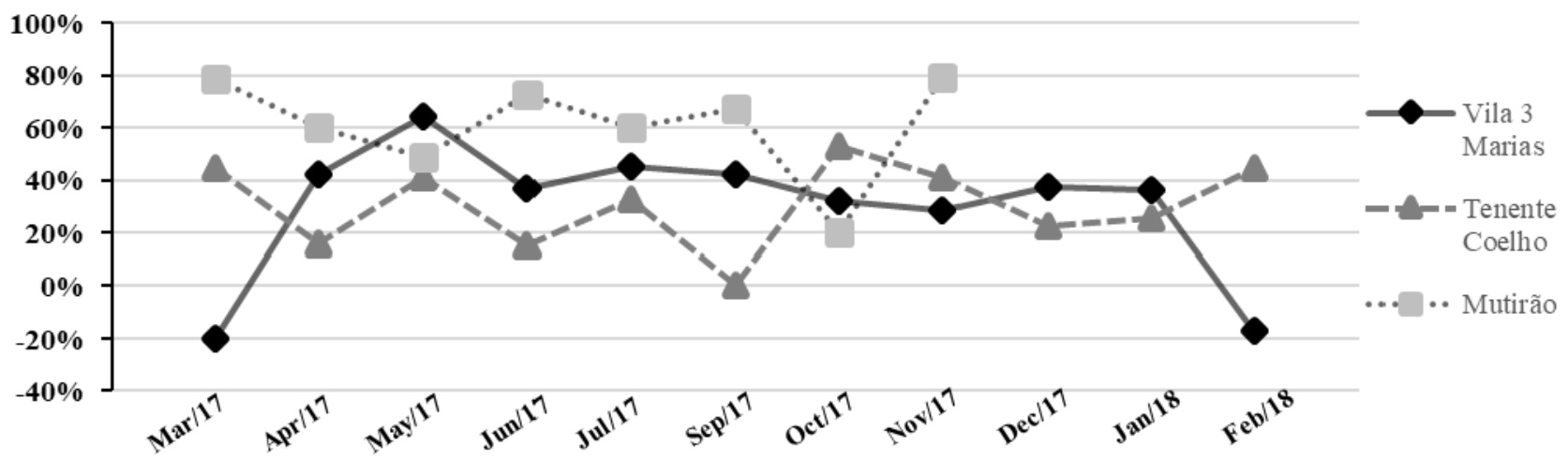

Fig. 2 Efficiency of COD removal at UASB stations in Juazeiro do Norte.

quality of the effluent, it was the one that had higher removal rates of COD, against WWTP Tenente Coelho and WWTP Vila Três Marias. However, in the months of December (2017) to February (2018) the CAGECE due to operational problems, did not carry out analyses of the quality of the effluent in this station. In addition, in September 2017 no analyses were carried out in two stations.

It is also verified through Fig. 2 that in the months of March/2017 and February/2018, there was negative efficiency of organic matter removal at Vila Três Marias station, that is, the organic load of the sewage dumped in the Salgado River is greater than organic load of raw sewage affluent to the season.

This fact can be explained by the occurrence of a possible overload of oils and greases in the reactor, thus causing the adsorption of fat in the bacterial sludge, causing a drag of solids and, therefore, influencing the organic matter removal in the reactor [13].

The average COD removal efficiencies are consistent with the values presented in the literature [27-29].

\subsection{Quality of the Treated Effluent}

\section{$3.1 .1 \mathrm{pH}$}

The quality of the effluent should meet the state regulations for the discharge of water bodies, in relation to the effluent of the UASB reactors, it is recommended post-treatment for a better efficiency of this system $[1,10]$. Fig. 3 shows the variation of $\mathrm{pH}$ in relation to the months at the UASB stations in the city, where there is a trend towards the neutrality range with the highest average $\mathrm{pH}$ at the station Tenente Coelho, corroborating with other studies in the literature $[30,31]$. The state standard establishes a $\mathrm{pH}$ range of 5.0 to 9.0 (Table 1), with all the stations under study complying with the legislation regarding this parameter (Fig. 3). The $\mathrm{pH}$ is an extremely important environmental condition in anaerobic processes, with an optimum $\mathrm{pH}$ range between 6.6 and 7.6; ideally between 7.0 and 7.2 [2]. The control process of this parameter must be made strictly, as it is affected by organic acids and the carbon dioxide de-equilibrium reactions [2]. The $\mathrm{pH}$ condition influences the development of the process, if the $\mathrm{pH}$ falls sharply, it means that the acids formed are not being neutralized by the absence of alkalinity in the medium, or not converted to methane gas, this process is known as reactor souring, leading to the collapse of the process [2]. In this case, the reactor after the souring process will only work again after the addition of external alkalinity [13].

\subsubsection{E. coli}

The state legislation establishes (Table 1) a maximum limit of $E$. coli in eviction after treatment of up to five thousand CFU (number of CFU) per 100 $\mathrm{mL}$. Fig. 4 shows the results analyzed in the three stations with UASB technology in Juazeiro do Norte in relation to this parameter. According to Fig. 3, Tenente Coelho and Mutirão WWTPs, during the 


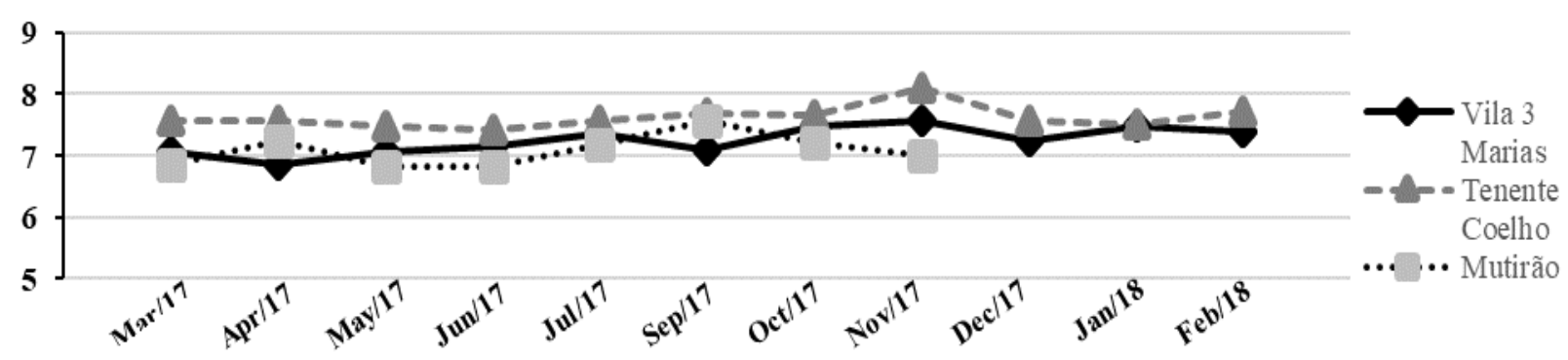

Fig. $3 \mathrm{pH}$ in function of the months in UASB reactors of Juazeiro do Norte.

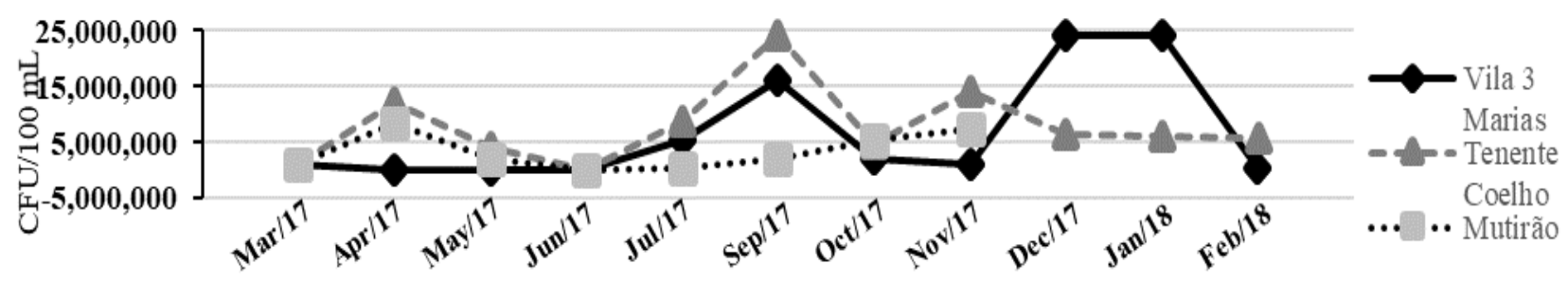

Fig. 4 E. coli in function of the months in UASB reactors of Juazeiro do Norte.

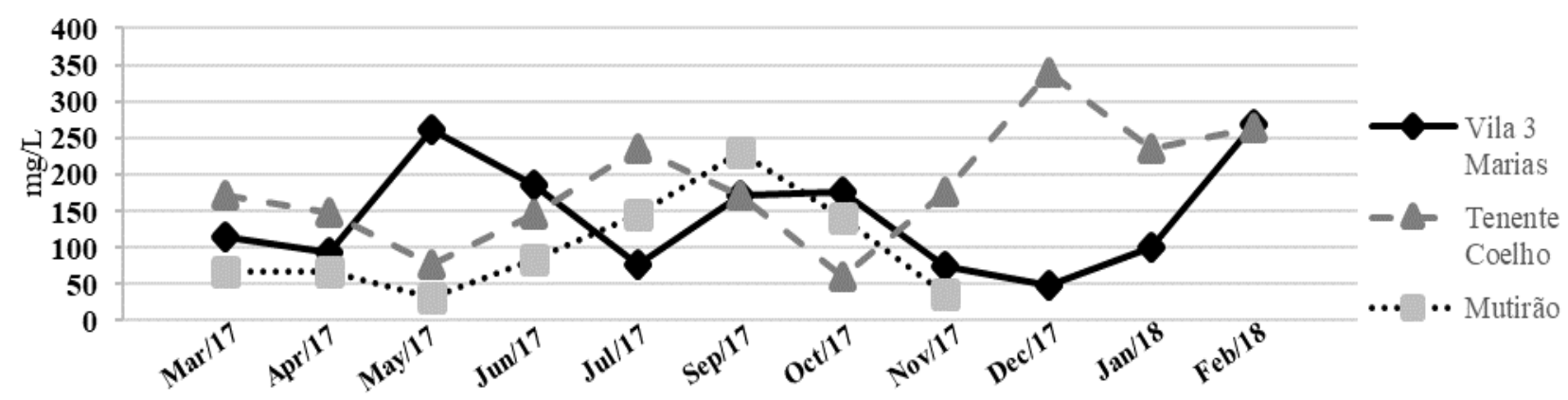

Fig. 5 TSS in function of the months in UASB reactors of Juazeiro do Norte.

whole analyzed period, did not present satisfactory results of $E$. coli equal to or below the maximum value allowed in the state standard.

The Vila 3 Marias WWTP (UASB + Chlorination) obtained a satisfactory result in the reduction of pathogens according to the legislation, only in the months of April (100 CFU/100 mL) and June (1 $\mathrm{CFU} / 100 \mathrm{~mL}$ ), the $E$. coli values in the treated effluent being still quite high when compared with some authors [32, 33]. Anaerobic reactors are not designed for the purpose of removal of microorganisms, this being a consequence of the retention of solids [14].

\subsubsection{TSS}

Fig. 5 shows the monthly concentrations of TSS at UASB WWTPs in Juazeiro do Norte.
In relation to the state legislation for the discharge of sewage treated in the environment (Table 2), according to Fig. 5, the Tenente Coelho WWTP (March, April, May, June, October and November) and Mutirão (April, July, November, December and February) obtained in five months values of compliance with resolution COEMA No. 02/2017 for the parameter TSS, against only two months (May and October) of the Tenente Coelho WWTP.

\subsection{Statistics of WWTPs}

Table 3 features measures of central tendency (average) and variation (minimum, maximum and standard deviation) of the UASB technology in Juazeiro do Norte operated by CAGECE. 
Table 3 Parameters analyzed.

\begin{tabular}{|c|c|c|c|c|c|}
\hline WWTP & Variable & $\mathrm{COD}(\mathrm{mg} / \mathrm{L})$ & TSS (mg/L) & $\mathrm{pH}$ & $\begin{array}{l}\text { E. coli } \\
(\mathrm{CFU} / 100 \mathrm{~mL})\end{array}$ \\
\hline \multirow{4}{*}{ Vila 3 Marias } & Average & 254.93 & 114.00 & 7.37 & $6.61 \mathrm{E}+06$ \\
\hline & Standard Deviation & 57.51 & 75.26 & 0.25 & $9.79 \mathrm{E}+06$ \\
\hline & Maximum & 361.39 & 268.00 & 7.66 & $2.40 \mathrm{E}+07$ \\
\hline & Minimum & 177.27 & 47.50 & 6.84 & $1.00 \mathrm{E}+00$ \\
\hline \multirow{4}{*}{ Tenente Coelho } & Average & 518.43 & 172.00 & 7.57 & $7.87 \mathrm{E}+06$ \\
\hline & Standard Deviation & 124.74 & 81.49 & 0.18 & $6.79 \mathrm{E}+06$ \\
\hline & Maximum & 773.49 & 340.00 & 8.09 & $2.40 \mathrm{E}+07$ \\
\hline & Minimum & 308.32 & 60.00 & 7.43 & $1.00 \mathrm{E}+00$ \\
\hline \multirow{4}{*}{ Mutirão } & Average & 297.63 & 75.35 & 7.09 & $1.80 \mathrm{E}+06$ \\
\hline & Standard Deviation & 187.57 & 67.72 & 0.26 & $3.25 \mathrm{E}+06$ \\
\hline & Maximum & 721.78 & 230.00 & 7.57 & $8.20 \mathrm{E}+06$ \\
\hline & Minimum & 200.54 & 30.50 & 6.82 & $1.00 \mathrm{E}+00$ \\
\hline
\end{tabular}

Table 3 shows that among the three WWTPs studied with respect to the parameter TSS, the Mutirão WWTP obtained the lowest mean concentration (75.35 mg/L) of TSS, when compared with the Vila Três Marias (114 mg/L) and Tenente Coelho (172 $\mathrm{mg} / \mathrm{L})$ WWTPs. The highest average of the Tenente Coelho station (UASB + SAF) can be attributed to aeration problems [34], since it is the only station that has an aeration system among the others, besides that this station in none of the months reached the expected quality of the effluent as for the parameter $\mathrm{TSS} \leq 30 \mathrm{mg} / \mathrm{L}[4]$.

Also, in Table 3, it can be inferred that the WWTP that obtained the highest COD averages was the Tenente Coelho WWTP, results that can be attributed to factors such as operational problems, bad station design, as well as problems of effluent distribution and hydraulic overload of the system.

\section{Conclusions}

The conclusions found in the study reveal that the treatment of domestic effluents through UASB reactor systems requires a later phase of treatment, since this technology without an adequate post-treatment had values well above those that are allowed in the state resolution for launching effluent in water bodies.

The performance of the UASB + SAF system stated that due to possible operational problems, they provided unsatisfactory average results for all parameters analyzed in this study (except $\mathrm{pH}$ ) and did not comply with the environmental legislation of the State of Ceará, regarding the discharge of domestic sewage in water bodies.

As a result of the low levels of compliance with the legislation, it is concluded that there is a need for the concessionaire to take emergency measures in order to ensure the proper and safe treatment of domestic effluents as well as disposal within established standards.

\section{References}

[1] Metcalf, J., and Eddy, H. P. 2014. Wastewater Engineering: Treatment and Resource Recovery. New York: McGraw-Hill.

[2] Dos Santos, A. 2007. Technical Evaluation of Sewage Treatment Systems. Fortaleza: BNB.

[3] Von Sperling, M. 2018. Principles of Biological Treatment of Wastewater: Introduction to Water Quality and Sewage Treatment. Belo Horizonte: UFMG.

[4] Jordão, E., and Pessôa, C. 2017. Treatment of Domestic Sewage. Rio de Janeiro: ABES.

[5] Mota, S. 2016. Introduction to Environmental Engineering. Rio de Janeiro: ABES.

[6] Teixeira, J., Oliveira, G., Viali, A., and Muniz, S. 2014. "Study of the Impact of Deficiencies of Sanitation on Public Health in Brazil from 2001 to 2009." Revista Brasileira de Engenheria Sanitária e Ambiental 19: 87-96.

[7] Paz, M., Almeida, M., and Gunter, W. 2012. "Diarrhea in Children and Sanitation and Housing Conditions in 
Periurban Areas in the City of Guarulhos, SP." Revista Brasileira de Epidemiologia 15: 188-97.

[8] Oliveira, A., Leite I., and Valente, J. 2015. "Global Burden of Diarrheal Disease Attributable to the Water Supply and Sanitation System in the State of Minas Gerais, Brazil." Revista Saúde Coletiva 20 (4): 1027-36.

[9] Fontenele, S., Andrade, E., Salgado, E., Meireles, A., and Sabiá, R. 2011. "Spatial-Temporal Analysis of Water Quality in the Upper Part of the Salgado River Basin, Ceará." Revista Caatinga 24 (3): 102-9.

[10] Chernicharo, C. 2016. Principles of Biological Treatment of Wastewater: Anaerobic Reactors. Belo Horizonte: UFMG.

[11] Foresti, E., Zaiat, M., and Vallero, M. 2006. "Anaerobic Processes as the Core Technology for Sustainable Domestic Wastewater Treatment: Consolidated Applications, New Trends, Perspectives, and Challenges, Reviews." Reviews in Environmental Science and Bio/Technology 5 (1): 3-19.

[12] Schultz, J., Pinheiro, A., and Da Silva, J. D. 2018. "Textile Biological Sludge Treatability and Biogas Production in UASB Reactor under Different Temperatures." Revista Brasileira de Engenharia Sanitária e Ambiental 23 (1): 151-8.

[13] Van Haandel, A. C., and Lettinga, G. 1994. Anaerobic Sewage Treatment: A Pratical Guide for Regions with a Hot Climate. Chichester: J. Willey.

[14] Van Haandel, A. C., and Marais, G. 1994. The Behavior of the Activated Sludge System: Theory and Applications for Projects and Operation. Campina Grande: Epigraf.

[15] Van Lier, J. 2008. "High-Rate Anaerobic Wastewater Treatment: Diversifying from End-of-the-Pipetreatment to Resource-Oriented Conversion Techniques." Water Science \& Technology 57 (8): 1137-48.

[16] Sobrinho, P. A., and Jordão, E. P. 2001. Post-Treatment of Effluents from Anaerobic Reactors-A Critical Analysis. In Post-Treatment of Effluents from Anaerobic Reactors. São Paulo: FINEP.

[17] Carvalho, G. M., Mendes, T. A., Garção, A. L., and Pasqualetto, A. 2017. "Use of Anaerobic Sludge Blanket Reactor (UASB) in the Food Industry as an Alternative for Treatment of Effluents in Areas without Sewage Collection Networks." Revista Gestão \& Sustentabilidade Ambiental 6 (1): 125-42.

[18] Filho, A. S. L. S., Mensah, J. H. R., Battiston, K. M., Barros, M. S., and Dos Santos, I. F. S. 2018. "Dimensioning of a UASB Reactor for Treatment of Domestic Effluents and Recovery of Biogas for Energy Production: A Case Study in Pouso Alegre (MG)." Revista Brasileira de Energias Renováveis 7 (1): 77-94.

[19] COEMA (State Council for the Environment). 2017. "Provides Standards and Conditions for the Discharge of
Liquid Effluents Generated by Polluting Sources." $\begin{array}{llll}\text { Accessed } & \text { May } & 2018 .\end{array}$ https://www.legisweb.com.br/legislacao/?id=33797.

[20] ARCE (Regulatory Agency of Delegated Public Services of the State of Ceará). 2018. Fiscalização no SAA e SES do Município de Juazeiro do Norte/CE. Accessed May 28, 2018. https://goo.gl/7Vskcc.

[21] SNIS (National Sanitation Information System). 2018. Accessed July 24, 2018. http://www.snis.gov.br.

[22] TRATA BRASIL (Instituto Trata Brasil). 2018. Ranking of Sanitation Instituto Trata Brasil 2018. Accessed July 10 ,

2018. http://www.tratabrasil.org.br/images/estudos/itb/ranking2018/realatorio-completo.pdf.

[23] CAGECE (Water and Sewage Company of Ceará). 2018. "Sampling Plan for Sewage Quality Monitoring-Indoor Business Units."

[24] Viana, L. F. G, Pinheiro, J. C. V., Sabiá, R. F., and Campos, R. T. 2013. "Demand for Raw Water for Domestic Sewage Dilution in the Salgado River Hydrographic Basin in Ceará: An Application of Demand All or Nothing." Revista Econômica do Nordeste 44 (3): 795-814. Accessed May 10, 2018. http://www.repositorio.ufc.br/bitstream/riufc/14221/1/201 2_art_jcvpinheiro.pdf.

[25] Rodríguez, A. L., Suaréz, J. S, Horta, J. Z. J., and Jácome, A. G. 2008. "Behavior of Anaerobic Digestion of Liquid Waste from the Sisal Industry on a Pilot Scale." Revista em Agronegócio e Meio Ambiente 1 (1): 77-86. Accessed May 22, 2018. http://periodicos.unicesumar.edu.br/index.php/rama/articl e/view/508/366.

[26] Pokrywiecki, T. S., Gumy, M. P., Tonial, I. B., and Pokrywiecki, J. C. 2013. "Evaluation of Treatment Process of Dairy Effluent." Revista Acadêmica de Ciências. Agrárias e Ambientais 11 (1): 155-61.

[27] Calijuri, M. A., Bastos, R. K. X., Magalhães, T. B., Capelete, B. C., and Dias, E. H. D. 2009. "Domestic Wastewater Treatment in UASB-horizontal Flow Constructed Wetlands Systems: Organic Matter, Solids, Nutrients and Coliforms Removal." Revista Brasileira de Engenharia Sanitária e Ambiental 14 (3): 421-30.

[28] Hirakawa, C., Piveli, R. P., and Sobrinho, P. A. 2002. "Submerged Aerated Biofilter Applied to Post-Treatment of UASB Reactor Effluent-Pilot Scale Study with Sanitary Sewage." Revista Brasileira de Engenharia Sanitária e Ambiental 14 (3): 421-30.

[29] Neto, M. S. A., and Oliveira, R. A. 2004. "Organic Matter, Nutrients and Coliforms Removal in Two-Stage Anaerobic Process (Anaerobic Baffled Reactor Followed by UASB Reactor) for Swine Wastewater Treatment." Engenharia Agrícola 29 (1): 148-61. 

Municipality of Juazeiro do Norte-Ceará

[30] Santos, E. M. A., Nascimento, A. T. P., Paulino, T. R. S., Barroso, B. C. S., and Aguiar, C. R. 2017. "Anaerobic Reactor Type UASB Conjunction with Process Fenton to Remove Color and Chemical Oxygen Demand Textile Industry of Synthetic Wastewater." Revista Brasileira de Engenharia Sanitária e Ambiental 22 (2): 285-92.

[31] Santos, V. S., Silva, L. M. M., Sousa, F. C., Santos, D. J., and Brito, A. S. 2012. "Evaluation of the Efficiency in the Removal of COD and BOD in an Upflow UASB Reactor and Sludge Blanket." Revista Verde de Agroecologia e Desenvolvimento Sustentável 7 (2): 16-20.

[32] Tawfik, A., Klapwijk, B., Buuren, J. V., El-Gohary, F., and Lettinga, G. 2004. "Physico-Chemical Factors
Affecting the E. coli Removal in a Rotating Biological Contactor (RBC) Treating UASB Efluente." Water Research 38 (5):1081-8.

[33] Basttiselli, A. A, Vidal, C. M. S., Souza, J. B., and Cavallini, G. S. 2016. "Tratamento avançado de efluente de reator UASB por membrana de microfiltração associado à desinfecção por radiação ultravioleta." Semina: Ciências Exatas e Tecnológicas 37 (1): 45-54. (in Portuguese)

[34] Ferraz, D. L. M. 2014. "Efficiency of a Full-Scale ETE Composed of UASB Reactor Followed by Activated Sludge." Accessed July 05, 2018. https://repositorio.ufrn. br/jspui/handle/123456789/16013. 